\title{
Corporate Governance dan Keputusan Pendanaan
}

\author{
Annisa Yasmin ${ }^{(1)}$ \\ Noorlaily Fitdiarini ${ }^{(2)}$ \\ Universitas Diponegoro ${ }^{(1)}$ \\ Universitas Airlangga ${ }^{(2)}$ \\ annisayasmin@lecturer.undip.ac.id ${ }^{(1)}$ \\ noorlaily-f@feb.unair.ac.id ${ }^{(2)}$
}

\begin{abstract}
This research aims to examine the influence of corporate governance on financing decisions or capital structures on manufacturing companies listed on the Indonesia Stock Exchange for the period 2008-2010. In this study, corporate governance was projected with board size, independent commissioner, managerial ownership, and institutional ownership, while funding decisions were projected with debt ratio. The technique used to test the influence of corporate governance on capital structures is using multiple linear regression analysis. The results found that board size and board composition have a significant negative effect on the capital structure, while managerial ownership, and institutional ownership do not have a significant influence on the capital structure.
\end{abstract}

Keywords: corporate governance; capital structure; financing decision; debt

\begin{abstract}
ABSTRAK
Penelitian ini bertujuan untuk menguji pengaruh dari corporate governance terhadap keputusan pendanaan atau struktur modal pada perusahaan manufaktur yang terdaftar di Bursa Efek Indonesia periode 2008-2010. Pada penelitian ini, corporate governance diproksikan dengan board size, independent commissioner, managerial ownership, dan institutional ownership, sedangkan keputusan pendanaan diproksikan dengan debt ratio. Teknik yang digunakan untuk menguji pengaruh corporate governance terhadap struktur modal adalah dengan menggunakan analisis regresi linier berganda. Hasil yang ditemukan adalah board size dan board composition berpengaruh negatif signifikan terhadap struktur modal, sedangkan managerial ownership, dan institutional ownership tidak mempunyai pengaruh yang signifikan terhadap struktur modal.
\end{abstract}

Kata kunci: corporate governance; capital structure; keputusan pendanaan; utang 


\section{PENDAHULUAN}

Keputusan pendanaan penting yang dihadapi oleh perusahaan adalah pilihan antara utang dan modal ekuitas (Glen dan Pinto, 1994). Struktur modal atau struktur keuangan dari perusahaan adalah gabungan spesifik dari utang dan ekuitas yang digunakan perusahaan untuk mendanai operasinya. Keputusan struktur modal penting untuk setiap organisasi bisnis, karena kebutuhan dari perusahaan untuk memaksimalkan pengembalian kepada pemegang saham dan juga karena keputusan ini berdampak pada kemampuan organisasi untuk menghadapi lingkungan yang kompetitif (Abor dan Biekpe, 2005). Kunci bagi perusahaan adalah untuk memilih portofolio struktur modal yang akan menjaga kontinuitas dan menghasilkan lebih banyak kekayaan. Secara umum, perusahaan dapat memilih di antara banyak struktur modal altematif. Hal ini dapat menghilangkan sejumlah besar utang atau sangat sedikit utang. Dalam upaya untuk membentuk struktur modal yang dapat memaksimalkan nilai pasar secara keseluruhan, perusahaan memiliki cara berbeda-beda dalam menghadapi masalah optimalisasi persyaratan struktur modal.

Corporate governance didefinisikan sebagai "suatu sistem yang berfungsi untuk mengarahkan dan mengendalikan organisasi” (Tjager et al, 2003, hal.26). Pengertian yang lebih luas mengklasifikasikan corporate governance ke dalam dua perspektif yaitu perspektif sempit dan perspektif luas. Dalam perspektif sempit, corporate governance didefinisikan sebagai mekanisme administratif yang mengatur hubungan antara manajemen perusahaan, komisaris, direksi, pemegang saham, dan kelompok kepentingan (stakeholders) yang lain, sedangkan dalam perspektif luas, corporate governance didefinisikan dengan sejauh mana perusahaan telah dijalankan dengan cara yang terbuka dan jujur untuk mempertebal kepercayaan masyarakat luas terhadap mekanisme pasar, meningkatkan efisiensi dalam alokasi sumber daya, baik dalam skala domestik maupun intemasional, memperkuat struktur industri, dan akhimya meningkatkan kemakmuran dan kesejahteraan masyarakat luas. Bamhart dan Rosenstein (1998) mengemukakan mekanisme corporate governance meliputi mekanisme intemal, seperti adanya struktur dewan direksi, kepemilikan manajerial, dan kompensasi eksekutif, sedangkan mekanisme ekstemal adalah kontrol perusahaan untuk pasar, kepemilikan institusional, dan tingkat pendanaan dengan utang (debt financing).

Corporate governance mengacu pada bagaimana perusahaan harus dijalankan, diarahkan, dan dikendalikan. Corporate governance yang baik akan mengarah kepada kepercayaan dan kemauan investor. Gompers et al. (2003) berpendapat bahwa good corporate governance akan meningkatkan penilaian dan meningkatkan bottom line (semua tindakan yang dapat meningkatkan atau mengurangi pendapatan bersih atau keuntungan perusahaan 
seluruhnya, perusahaan yang meningkatkan pendapatan bersih atau mengurangi biaya dikatakan akan meningkatkan bottom line). Claessens et al. (2002) juga berpendapat bahwa kerangka kerja perusahaan yang lebih baik akan menguntungkan perusahaan melalui akses yang lebih besar untuk pembiayaan, biaya modal yang lebih rendah, kinerja yang lebih baik dan perlakuan yang lebih baik terhadap semua stakeholder.

Corporate governance yang buruk akan menyebabkan kinerja perusahaan yang buruk dan pola pembiayaan yang berisiko, serta tidak kondusif ketika menghadapi krisis ekonomi makro (Claessens et al., 2002), seperti krisis yang terjadi di Asia Timur tahun 1997. Bech et al. (2002) mengidentifikasi sejumlah alasan yang menyebabkan semakin pentingnya tata kelola perusahaan, termasuk gelombang privatisasi global pada dua dekade terakhir, reformasi dana pensiun dan pertumbuhan tabungan swasta, gelombang takeover tahun 1980-an, deregulasi dan integrasi pasar modal, krisis Asia Timur tahun 1997, dan serangkaian skandal korporasi terbaru di Amerika Serikat dan tempat lain.

Isu mengenai Good Corporate Governance (GCG) saat ini sedang hangat diperbincangkan, terlebih dikalangan ekonom dan pelaku bisnis di Indonesia. Sejak adanya krisis finansial di berbagai negara khususnya Indonesia pada tahun 1997, yang akhimya berubah menjadi krisis finansial Asia dipandang sebagai akibat dari lemahnya praktik GCG di negara-negara Asia. Tjager, et al., (2003) menyatakan krisis ini disebabkan adanya kondisikondisi objektif yang relatif sama di negara-negara tersebut antara lain adanya hubungan yang erat antara pemerintah dan pelaku bisnis, konglomerasi dan monopoli, proteksi, dan intervensi pasar sehingga membuat negara-negara tersebut tidak siap memasuki era globalisasi dan pasar bebas. Dalam bahasa khusus, korporat negara kita belum menjalankan governance (Moeljono). Survey dari Booz-Allen di Asia Timur pada tahun 1998 menunjukkan bahwa Indonesia memiliki indeks corporate governance paling rendah dengan skor 2,88 jauh di bawah Singapura $(8,93)$, Malaysia $(7,72)$ dan Thailand $(4,89)$. Rendahnya kualitas GCG korporasi-korporasi di Indonesia ditengarai menjadi kejatuhan perusahaan-perusahaan tersebut.

Pada tahun 2005, 2006, dan 2007 berdasarkan hasil program riset dan pemeringkatan CGPI di Indonesia terdapat dua perusahaan yang terpredikat "sangat terpercaya" dan 13 perusahaan yang terpredikat "terpercaya". Tahun 2008 dan 2009 terdapat lima perusahaan terpredikat "sangat terpercaya" dan 16 perusahaan terpredikat terpercaya. Dari fakta tersebut dapat dilihat apabila di Indonesia praktik good corporate governance telah mengalami peningkatan dalam penerapannya pada perusahaan di Indonesia. Penelitian ini mencoba untuk melihat apakah peningkatan penerapan good corporate governance mempengaruhi keputusan pendanaan perusahaan dalam menggunakan utang. 
Corporate governance telah diidentifikasi dalam studi sebelumnya untuk mempengaruhi keputusan pendanaan atau keputusan struktur modal yang mana juga mempengaruhi kinerja perusahaan (Abor, 2007; Berger et al., 1997; Friend dan Lang, 1988). Studi-studi empiris cenderung untuk fokus terutama pada negara-negara maju dengan hasil meyakinkan. Untuk meneliti hubungan antara corporate governance terhadap keputusan pendanaan digunakan beberapa faktor sebagai berikut: ukuran anggota direksi, komposisi dewan direksi, dualitas CEO, kepemilikan manajerial, dan kepemilikan institusional.

Perbedaan penelitian ini dengan penelitian-penelitian sebelumnya adalah pada penelitian ini digunakan variabel-variabel gabungan dari penelitian-penelitian sebelumnya yaitu board size, board composition, managerial ownership, institutional ownership pada perusahaanperusahaan manufaktur yang listing di BEI (Bursa Efek Indonesia) sebagai objek penelitian. Berdasarkan latar belakang di atas maka penelitian ini bertujuan untuk meneliti bagaimana pengaruh dari corporate governance terhadap keputusan pendanaan perusahaan manufaktur yang terdaftar di BEI periode 2008-2010.

\section{Corporate Governance}

Corporate governance adalah keseluruhan set aransemen legal, kebudayaan, dan institusional yang menentukan apa yang dapat dilakukan oleh perusahaan publik, siapa yang mengendalikan, bagaimana pengendalian dilakukan, dan bagaimana risiko dan retum dari aktivitas-aktivitas yang dilakukan oleh perusahaan tersebut dilokasikan (Blair, 1995; Sukariana dan Darma, 2015; Widiatmika dan Darma, 2018). Mayer (1996) menyatakan apabila corporate governance berkenaan dengan cara untuk membawa kepentingan agen (manajer) dan prinsipal (investor) sejalan dan menjamin agar perusahaan dijalankan bagi kemanfaatan prinsipal (investor). Corporate governance didefinisikan sebagai susunan aturan yang menentukan hubungan antara pemegang saham, manajer, kreditor, pemerintah, karyawan dan stakeholder intemal dan ekstemal yang lain sesuai dengan hak dan tanggung jawabnya (FCGI, 2003). Berikutnya dikemukakan oleh OECD (2004) good corporate governance merupakan satu set hubungan antara manajemen perusahaan, dewan, pemegang saham, dan pemangku kepentingan lainnya. Sehingga dapat diambil kesimpulan apabila corporate governance adalah suatu cara yang mengatur hubungan-hubungan antara manajemen perusahaan, komisaris, direksi, pemegang saham dan stakeholders lainnya.

Prinsip-prinsip corporate governance yang dikemukakan oleh OECD ada lima. Kelima prinsip tersebut adalah hak-hak pemegang saham, perlakuan yang adil kepada pemegang saham, peranan stakeholders dalam corporate governance, transparansi dan tanggung jawab 
direksi. Sementara lima pilar GCG yang ditetapkan oleh Komite Nasional Kebijakan Governance (KNKG) adalah transparency, accountability, responsibility, independency, dan faimess atau biasa disebut dengan TARIF.

Menurut Forum Corporate Governance in Indonesia (FCGI) tujuan dari corporate governance adalah untuk menciptakan nilai tambah (value added) bagi semua pihak yang berkepentingan (stakeholders). Corporate governance juga diharapkan mampu mengurangi masalah keagenan (agency problem). Dengan adanya good corporate governance, maka diharapkan perusahaan akan dinilai baik oleh investor, sehingga pada akhimya dapat memengaruhi kelangsungan hidup perusahaan.

\section{Keputusan Pendanaan}

Keputusan pendanaan berkaitan dengan pemilihan sumber dana, baik yang berasal dari intemal maupun ekstemal, sangat mempengaruhi nilai perusahaan. Sumber dana intemal perusahaan berasal dari utang dan penerbitan saham (ekuitas). Proporsi antara penggunaan modal sendiri dan utang dalam memenuhi kebutuhan dana perusahaan disebut dengan struktur modal perusahaan. Ada banyak faktor yang mempengaruhi keputusan struktur modal, sehingga perusahaan yang berada dalam industri yang sama seringkali mempunyai struktur modal yang berbeda. Kebijakan struktur modal melibatkan perimbangan antara resiko dan tingkat pengembalian. Menggunakan lebih banyak utang berarti memperbesar resiko disatu sisi dan memperbesar tingkat pengembalian di sisi lain.

Struktur modal yang optimal suatu perusahaan harus berada pada keseimbangan antara resiko dan pengembalian yang memaksimumkan harga saham (Brigham dan Houston, 2001:56). Sedangkan menurut Van Home dan Wachowicz (1998:459), struktur modal optimal bagi seluruh perusahaan dalam industri membutuhkan proporsi utang yang lebih tinggi dari ekuitas. Komponen struktur modal terdiri dari ekuitas (modal sendiri) dan utang.

Menurut Husnan (2006:275-276) sumber modal sendiri perusahaan dapat berasal dari dalam perusahaan maupun dari luar perusahaan. Sumber dari dalam (intemal financing) berasal dari hasil operasi (laba) yang ditahan. Sedangkan sumber dari luar dapat dalam bentuk saham biasa atau saham preferen. Menurut Gitman (2003:522) "the two basic sources of equity capital are preffered stock and common stock equity, which includes common stock and retained eamings". Jadi dua sumber dasar modal sendiri adalah saham preferen dan modal biasa yang terdiri dari saham biasa dan laba ditahan. Riyanto (2005:240-244) mengungkapkan bahwa modal sendiri terdiri dari modal saham, cadangan dan laba ditahan. Modal saham terdiri dari saham biasa dan saham preferen. Cadangan yang dimaksud disini adalah cadangan yang 
dibentuk dari keuntungan yang diperoleh perusahaan selama beberapa waktu atau dari tahun yang berjalan. Sedangkan laba ditahan merupakan keuntungan yang diperoleh suatu perusahaan yang tidak dibayarkan kepada pemegang saham dalam bentuk dividen. Bila terdapat keuntungan yang tidak dibagikan untuk suatu tujuan tertentu, maka dibentuk cadangan seperti yang telah diuraikan sebelumnya. Tetapi jika perusahaan belum mempunyai tujuan tertentu, maka keuntungan yang tidak dibagikan tersebut dimasukkan dalam laba ditahan (retained eaming). Dari kedua pengertian tersebut dapat diambil suatu persamaan bahwa sumber modal sendiri bisa berasal dari saham biasa, saham preferen dan laba ditahan.

Laba ditahan (retained eaming) merupakan penjumlahan laba yang tidak dibagikan sebagai dividen dari tahun-tahun sebelumnya sampai sekarang. Saldo laba yang tidak dibagi sewaktu-waktu dapat diminta sebagai dividen oleh pemegang saham melalui Rapat Umum Pemegang Saham (RUPS). Laba yang tidak dibagikan ini diinvestasikan lagi ke perusahaan. Jumlah yang terkandung di dalam akun laba ditahan tidak hanya dipengaruhi oleh laba yang berhasil didapatkan oleh perusahaan tetapi dipengaruhi juga oleh kebijakan dividen yang diterapkan oleh perusahaan.

Utang yang dimiliki oleh perusahaan dibagi menjadi dua bagian besar yaitu utang jangka pendek dan utang jangka panjang. Menurut PSAK no 1 (2004) suatu kewajiban diklasifikasikan sebagai kewajiban jangka pendek jika: (a) diperkirakan akan diselesaikan dalam jangka waktu siklus normal operasi perusahaan, atau (b) jatuh tempo dalam jangka waktu dua belas bulan dari tanggal neraca. Menurut Niswonger et.al (2009) kewajiban lancar adalah kewajiban yang harus dipenuhi dengan aktiva lancar dan jatuh tempo dalam periode waktu yang pendek biasanya satu tahun.

Menurut Shiegel and Shin (2009:275) utang jangka panjang adalah uang yang dipinjam dalam jangka waktu lebih dari satu tahun. Utang jangka panjang juga biasa disebut utang pendanaan yang artinya pendanaan yang pada mulanya menggunakan utang jangka pendek digantikan dengan sekuritas yang jatuh temponya lebih panjang. Utang jangka panjang yang digunakan berupa pinjaman berjangka, obligasi, wesel bayar dengan jaminan atau tanpa jaminan (Weston and Bigham, 2003:741). Sedangkan menurut Husnan (2006:282) utang jangka panjang terdiri dari obligasi, kredit investasi dan hipotek.

\section{Pengaruh Corporate Governance kepada Keputusan Pendanaan}

Hasil dari Wen et al. (2002) menunjukkan hubungan yang positif antara ukuran dewan komisaris dan solvabilitas permodalan (struktur modal). Penemuan mereka menunjukkan bahwa dewan komisaris yang lebih besar, dimana lebih aman karena pemantauan yang lebih 
unggul oleh badan pengawas, mengejar leverage yang lebih tinggi untuk meningkatkan nilai perusahaan. Alasan lain adalah dewan komisaris yang lebih besar akan kesulitan dalam menghasilkan kemufakatan dalam membuat keputusan. Konflik-konflik yang timbul dari ukuran dewan komisaris yang lebih besar mempunyai kecenderungan untuk melemahkan corporate governance dan akan menghasilkan leverage yang lebih tinggi.

Pendekatan yang dikembangkan oleh Pfeffer (1973) dan Pfeffer dan Salancick (1978), menekankan bahwa dewan komisaris independen akan menambah kemampuan perusahaan untuk melindungi dirinya sendiri dalam melawan lingkungan ekstemal, mengurangi ketidakpastian, atau memberikan banyak pilihan untuk sumber daya yang akan meningkatkan kemampuan perusahaan untuk meningkatkan dana atau meningkatkan status dan pengakuan perusahaan tersebut. Tingginya proporsi dewan komisaris independen diyakini terkait dengan posisi leverage yang lebih tinggi.

Friend dan Lang dalam Brailsford et al. (1999) menyatakan bahwa manajer yang bertindak sebagai pemegang saham tentu akan bertindak lebih hati-hati terutama dalam hal pengambilan kebijakan utang untuk menghindari terjadinya kesulitan keuangan atau kebangkrutan usaha. Salah satu cara untuk menghindari resiko tersebut adalah dengan menekan jumlah utang yang dimiliki perusahaan. Selain itu adanya kepemilikan manajerial dalam struktur kepemilikan saham perusahaan, akan membuat kreditur melihat kinerja manajemen yang lebih baik. Sehingga resiko perusahaan dinilai rendah di mata kreditur.

Hubungan antara struktur kepemilikan terhadap struktur modal negatif dapat ditemukan dari studi empirik Chaganti and Damanpour (2001), Grier and Zychowicz (2004), Bathala et al. (2004) dan Crutcley and Jensen (2006) dimana disimpulkan bahwa terdapat hubungan yang negatif antara institusional ownership dan leverage. Hasil penelitian ini sesuai dengan pendapat yang disampaikan Tong and Ning (2004) menyatakan struktur modal yang ditunjukkan dalam rasio leverage yang tinggi akan memberikan sinyal negatif. Sinyal negatif yang dimaksud karena investor menganggap hal tersebut sebagai gambaran bahwa kondisi keuangan perusahaan di masa yang akan datang yang lebih rentan pada kondisi kesulitan keuangan. Sehingga investor lebih tertarik pada leverage yang rendah.

\section{Faktor-faktor yang Mempengaruhi Keputusan Pendanaan}

Perusahaan kecil akan cenderung menggunakan biaya modal sendiri dibanding biaya utang jangka panjang yang lebih mahal (Abor, 2007). Maka perusahaan kecil akan cenderung menyukai utang jangka pendek dari pada utang jangka panjang karena biayanya lebih rendah. 
Demikian juga dengan perusahaan besar akan cenderung memiliki sumber pendanaan yang kuat. Dengan demikian ukuran perusahaan akan memiliki pengaruh terhadap struktur modal.

Menurut Weston dan Brigham (1998:713), perusahaan dengan tingkat retum on assets yang tinggi, umumnya menggunakan utang dalam jumlah yang relatif sedikit. Hal ini disebabkan dengan retum on assets yang tinggi tersebut, memungkinkan bagi perusahaan melakukan permodalan dengan laba ditahan saja.

Risiko adalah sesuatu yang selalu dikaitkan dengan kemungkinan terjadinya keadaan yang merugikan dan tidak diduga sebelumnya bahkan bagi kebanyakan orang tidak menginginkannya. Pada penelitian Prabansari dan Kusuma (2006) menunjukkan jika risiko bisnis yang dialami perusahaan mempunyai pengaruh negatif terhadap struktur modal perusahaan.

Berdasarkan penelitian Abor (2007), pertumbuhan perusahaan yang tinggi menempatkan permintaan yang besar pada dana intemal umum perusahaan dan karena itu bergantung pada utang yang lebih sedikit. Perusahaan yang tumbuh dengan pesat sering menghadapi ketidakpastian yang lebih besar, yang cenderung mengurangi keinginan untuk menggunakan utang.

\section{Hipotesis dan Model Penelitian}

Berdasarkan rumusan masalah, landasan teori, dan penelitian sebelumnya, hipotesis dari penelitian ini adalah:

$\mathrm{H}_{1}$ : Board size berpengaruh positif signifikan terhadap keputusan pendanaan

$\mathrm{H}_{2}$ : Independent commissioner berpengaruh positif signifikan terhadap keputusan pendanaan

$\mathrm{H}_{3}$ : Managerial ownership berpengaruh negatif signifikan terhadap keputusan pendanaan

$\mathrm{H}_{4}$ : Institutional ownership berpengaruh positif signifikan terhadap keputusan pendanaan

Model analisis yang digunakan pada penelitian ini untuk melihat pengaruh corporate governance terhadap keputusan pendanaan adalah:

$$
\begin{aligned}
\mathrm{DR}_{i, t}= & \beta_{0}+\beta_{1} \mathrm{BS}_{i, t}+\beta_{2} \mathrm{IND}_{i, t}+\beta_{3} \mathrm{OWN}_{i, t}+\beta_{4} \mathrm{INS}_{i, t}+\beta_{5} \mathrm{SIZE}_{i, t}+\beta_{6} \mathrm{ROA}_{i, t}+\beta_{7} \mathrm{RISK}_{i, t}+ \\
& \beta_{8} \mathrm{GROW}_{i, t}+\ddot{\mathrm{e}}
\end{aligned}
$$

\section{METODE PENELITIAN}

Berdasarkan variabel-variabel yang hendak diteliti dan model penelitian, maka penelitian ini menggunakan pendekatan kuantitatif untuk menjawab rumusan masalah. Pendekatan ini menitikberatkan pada pengujian hipotesis dengan menggunakan data terukur dan alat statistik multiple regression linier analysis. Berdasarkan tujuan penelitian yang hendak dicapai, maka penelitian ini dapat digolongkan sebagai explanatory research (penelitian penjelasan) yang 
akan memberikan penjelasan mengenai hubungan kausal (sebab akibat) antara variabel bebas dengan variabel terikat. Menurut Singarimbun dan Effendi (2005) penelitian explanatory adalah penelitian untuk menjelaskan hubungan kausal antara variabel-variabel melalui pengujian hipotesa.

Dengan demikian, alasan digunakan penelitian explanatory ini adalah untuk menguji hipotesis yang telah dirumuskan yaitu faktor-faktor corporate governance, board size, independent commissioner, managerial ownership, dan institutional ownership mempunyai pengaruh secara signifikan terhadap keputusan pendanaan perusahaan manufaktur yang listing di Bursa Efek Indonesia tahun 2008-2010. V

Variabel-variabel yang akan diteliti dalam penelitian ini dapat diklasifikasikan atas dua kelompok variabel yaitu:

1. Variabel bebas (independent variable). Variabel bebas atau (X) dalam penelitian ini adalah board size (BS), independent commissioner (IND), managerial ownership (OWN), institutional ownership (INS);

2. Variabel terikat (dependent variable). Variabel terikat atau $(\mathrm{Y})$ dalam penelitian ini adalah variabel struktur modal perusahaan yaitu debt ratio (DR);

3. Variabel kontrol (control variable). Variabel kontrol dalam penelitian ini adalah ukuran perusahaan (SIZE), retum on activity (ROA), degree of operating leverage (DOL), pertumbuhan perusahaan (GROW).

Dalam rangka memudahkan pemahaman dan menghindari kesalahan penilaian, indikator serta variabel-variabel yang akan digunakan dalam penelitian ini perlu didefinisikan dengan cara memberi arti maupun menspesifikasikan kegiatan yang diperlukan untuk mengukur variabel-variabel tersebut.

1. Keputusan pendanaan merupakan komposisi antara sejauh mana perusahaan mampu membayar utang baik jangka panjang dan pendek dari total aset dan total ekuitas yang dimiliki perusahaan. Rumus yang digunakan untuk mengukur struktur modal adalah:

$$
\text { debt ratio }=\frac{\text { total debt }}{\text { total equity }+ \text { total debt }}
$$

2. Dewan komisaris dalam penelitian ini diukur dengan menggunakan logaritma dari jumlah anggota dewan komisaris yang dimiliki suatu perusahaan.

3. Independent commissioner dalam penelitian ini adalah perbandingan jumlah komposisi dewan komisaris independen yang dimiliki suatu perusahaan terhadap jumlah seluruh anggota dewan komisaris yang dihitung dengan rumus: 


$$
I N D=\frac{\text { jumlah dewan komisaris luar }}{\text { jumlah seluruh anggota dwwan komisaris }}
$$

4. Kepemilikan manajerial (managerial ownership) atau biasa sering disebut insider investor merupakan pemegang saham yang berasal dari dalam perusahaan seperti manajer dan direktur atau owner. Kepemilikan manajerial dapat diperoleh dengan rumus:

$$
\text { OWN }=\frac{\text { total kepemilikan individual }}{\text { jumlah saham beredar }}
$$

5. Kepemilikan institusional (institutional ownership) atau sering disebut outsider investor merupakan pemegang saham yang berasal dari luar perusahaan baik masyarakat umum, pemerintah, perusahaan, atau institusi tertentu. Kepemilikan institusional dapat diperoleh dengan rumus:

$$
I N S=\frac{\text { total kepemilikan institusional }}{\text { jumlah saham beredar }}
$$

6. Ukuran Perusahaan (Firm Size) merupakan ukuran atau besamya asset yang dimiliki perusahaan. Rumus yang digunakan untuk mengukur ukuran perusahaan adalah:

$$
S I Z E=\log (\text { total aset })
$$

7. Retum on Asset (ROA) merupakan rasio antar laba bersih yang berbanding terbalik dengan keseluruhan aktiva untuk menghasilkan laba. Rasio ini menunjukan berapa besar laba bersih yang diperoleh perusahaan diukur dari nilai aktivanya. Rumus untuk menghitung ROA adalah:

$$
R O A=\frac{\text { laba bersih }}{\text { total aset }}
$$

8. Degree of operating leverage (DOL) dimaksudkan untuk mengukur persentase perubahan laba operasi karena adanya persentase perubahan penjualan. Rumus untuk menghitung DOL adalah:

$$
D O L=\frac{\Delta E B I T}{\Delta \text { penjualan }}
$$

9. Pertumbuhan (growth) perusahaan diukur dari pertumbuhan dari penjualan yang didapatkan perusahaan dari tahun ke tahun.

$$
\text { growth }=\frac{\text { sales }_{t}-\text { sales }_{t-1}}{\text { sales }_{t-1}}
$$

Data yang digunakan pada penelitian ini adalah data sekunder, yaitu data atau laporan keuangan perusahaan sampel yang dipublikasikan melalui Bursa Efek Indonesia, ICMD 20082010, dan www.iicg.org. Dengan kata lain sumber data yang diperoleh peneliti secara tidak langsung dari perusahaan melainkan melalui media perantara (diperoleh dan dicatat oleh pihak 
lain). Data sekunder yang digunakan pada penelitian ini antara lain laporan keuangan perusahaan yang masuk dan tercatat di Bursa Efek Indonesia periode 2008 sampai dengan 2010 yang bukan perusahaan sektor keuangan (perbankan atau asuransi).

Populasi sasaran penelitian adalah seluruh perusahaan yang listing di Bursa Efek Indonesia. Dari populasi sasaran tersebut, sampel ditentukan secara tidak acak atau bersifat purposive sampling. Menurut Indriantoro dan Supomo (2009) purposive sampling artinya populasi yang akan dijadikan sample penelitian adalah populasi yang memenuhi kriteria tertentu yang dikehendaki peneliti. Sampel yang dipakai adalah perusahaan manufaktur yang listing di Bursa Efek Indonesia periode 2008 sampai dengan 2010. Untuk bisa menjawab hipotesis digunakan analisis regresi linier berganda (Multiple Linier Regression Analysis). Uji ini adalah alat analisis peramalan nilai pengaruh dua variabel bebas atau lebih terhadap satu variabel terikat untuk membuktikan ada atau tidaknya hubungan fungsional atau hubungan kausal antara variabel bebas (independent variable) dengan variabel terikat (dependent variable), (Riduwan, 2003).

\section{HASIL DAN PEMBAHASAN}

Setelah data memenuhi serangkaian uji asumsi regresi yang telah dilakukan sebelumnya maka dapat dilakukan pengujian terhadap model terpilih untuk membuktikan hipotesis. Berikut adalah hasil uji regresi linier berganda yang telah dilakukan:

Tabel 1.

Hasil Regresi Linier Berganda

\begin{tabular}{ccccc}
\hline Variabel & \multicolumn{2}{c}{ Unstandardized Coefficients } & \multirow{2}{*}{ T } & \multirow{2}{*}{ Sig } \\
\cline { 2 - 3 } & B & Standard Error & & \\
\hline Board size & -0.208 & 0.088 & -2.355 & 0.020 \\
Independent Commissioner & -0.247 & 0.082 & -3.022 & 0.003 \\
Managerial ownership & -1.059 & 0.702 & -1.508 & 0.134 \\
Institutional ownership & -0.156 & 0.077 & -2.017 & 0.045 \\
Size & 0.019 & 0.018 & 1.062 & 0.290 \\
ROA & -0.312 & 0.097 & -3.197 & 0.002 \\
DOL & 0.000 & 0.000 & -0.748 & 0.456 \\
Growth & 0.000 & 0.003 & -0.090 & 0.928 \\
Constanta & 0.624 & 0.202 & 3.098 & 0.002 \\
Koefisien Korelasi (R) & & $=0.404$ & & \\
Koefisien Determinasi $\left(\mathrm{R}^{2}\right)$ & & $=0.163$ & &
\end{tabular}




$\begin{array}{ll}\text { Adj. R. Square } & =0.119 \\ \text { Uji F } & =3.731 \\ \text { Signifikansi } & =0.001 \\ \text { Variabel Dependen } & \text { Debt Ratio (DR) }\end{array}$

Sumber: Peneliti (2012)

Hasil pengujian board size menunjukkan adanya pengaruh negatif signifikan terhadap keputusan pendanaan perusahaan manufaktur yang terdaftar di BEI periode tahun 2008-2010. Hal ini mengindikasikan jika semakin besar jumlah dewan komisaris maka semakin menurun struktur modal perusahaan dan sebaliknya semakin menurun board size maka semakin meningkat struktur modal perusahaan.

Hasil penelitian ini tidak sesuai dengan hipotesis awal, karena pada kenyataannya di Indonesia, perusahaan dengan ukuran dewan komisaris yang lebih besar akan menyebabkan tekanan kuat dari dewan komisaris untuk membuat manajer mengejar utang yang lebih rendah untuk meningkatkan kinerja perusahaan sesuai dengan pendapat yang disampaikan Pfeffer dan Salancick (1978), Lipton dan Lorsch (1992) yang menjelaskan bahwa ada hubungan negatif signifikan antara struktur modal dan ukuran dewan komisaris.

Selain itu penggunaan utang yang menurun dari tahun 2008 ke 2009 yang dilihat dari rata-rata total utang perusahaan sampel sebesar 2.29 persen dan dari tahun 2009 ke 2010 sebesar 11.84 persen disebabkan oleh adanya krisis ekonomi global pada tahun 2008. Ketika krisis ekonomi global terjadi penjualan perusahaan yang turun akan menyebabkan EBIT turun dan mengakibatkan kemampuan perusahaan membayar beban tetap menurun, sehingga perusahaan akan lebih menggunakan utang yang rendah untuk mengurangi beban tetap.

Hasil pengujian independent commissioner menunjukkan adanya pengaruh negatif signifikan terhadap keputusan pendanaan perusahaan manufaktur yang terdaftar di BEI periode 2008-2010. Hal ini mengindikasikan jika semakin tinggi jumlah dewan komisaris independen, maka struktur modal perusahaan akan semakin turun dan sebaliknya apabila jumlah dewan komisaris independen menurun, maka struktur modal perusahaan akan semakin meningkat.

Hasil yang menunjukkan adanya hubungan negatif signifikan antara jumlah dari dewan komisaris independen pada dewan komisaris dan utang ini sejalan dengan penelitian Wen et al. (2002). Dewan komisaris independen cenderung lebih aktif memantau manajer, menyebabkan manajer mengadopsi leverage yang lebih rendah untuk mendapatkan hasil kinerja yang lebih baik. Perusahaan dengan proporsi dewan komisaris independen yang lebih besar cenderung mengejar financial leverage yang lebih rendah dengan nilai ekuitas pasar yang 
lebih tinggi. Hasil yang negatif pada penelitian ini disebabkan adanya krisis ekonomi global pada tahun 2008. Krisis ekonomi global menyebabkan perusahaan menggunakan utang yang lebih rendah untuk meringankan beban tetap perusahaan. Penggunaan utang yang lebih rendah dapat dilihat dari rata-rata penggunaan utang perusahaan sampel yang menurun dari tahun 2008 ke 2009 sebesar 2.29 persen dan dari tahun 2009 ke 2010 sebesar 11.84 persen.

Hasil pengujian managerial ownership menunjukkan bahwa managerial ownership berpengaruh negatif tidak signifikan terhadap keputusan pendanaan perusahaan manufaktur yang terdaftar di BEI periode 2008-2010. Hal ini mengindikasikan jika semakin tinggi jumlah kepemilikan manajerial, maka struktur modal perusahaan akan semakin turun dan sebaliknya apabila kepemilikan manajerial menurun, maka struktur modal perusahaan akan semakin meningkat. Hasil yang menunjukkan adanya hubungan negatif tidak signifikan ini tidak sejalan dengan penelitian Anderson et al. (2005) dan Friend dan Lang dalam Brailsford et al. (1999).

Hasil yang tidak signifikan dalam penelitian ini menunjukk:an bahwa jumlah kepemilikan manajerial tidak mutlak memiliki hubungan terhadap peningkatan atau penurunan dari struktur modal perusahaan-perusahaan manufaktur yang menjadi sampel. Adanya kepemilikan manajerial dalam kepemilikan saham perusahaan seharusnya memberikan dorongan bagi pihak manajemen untuk berpihak terhadap pemegang saham untuk mengejar utang yang lebih rendah. Akan tetapi, proporsi kepemilikan manajerial yang cenderung sedikit menyebabkan pihak manajemen tidak mempunyai kendali dalam menentukan kebijakan utang karena banyak dikendalikan oleh pemilik mayoritas. Hubungan yang negatif antara managerial ownership terhadap utang menunjukk:an jika manajer yang bertindak sebagai pemegang saham akan menggunakan utang yang lebih kecil untuk meningkatkan dividen sahamnya dan untuk menghindari terjadinya kesulitan keuangan atau kebangkrutan usaha, sehingga semakin besar manajer yang bertindak sebagai pemegang saham, akan menyebabkan kebijakan pendanaan menggunakan utang lebih kecil.

Hasil pengujian institutional ownership menunjukkan bahwa institutional ownership berpengaruh negatif signifikan terhadap keputusan pendanaan perusahaan manufaktur yang terdaftar di BEI periode 2008-2010. Hal ini mengindikasikan jika semakin tinggi jumlah kepemilikan institusional, maka struktur modal perusahaan akan semakin turun dan sebaliknya apabila kepemilikan institusional menurun, maka struktur modal perusahaan akan semakin meningkat. Hasil yang menunjukkan arah negatif signifikan dalam penelitian ini menunjukkan bahwa jumlah kepemilikan saham institusional memiliki hubungan terhadap peningkatan atau penurunan dari struktur modal perusahaan-perusahaan manufaktur yang menjadi sampel. Hasil ini menunjukkan apabila investor institusional akan melakukan pengawasan yang lebih 
mendalam terhadap manajemen supaya menggunakan utang yang lebih rendah dalam pendanaan perusahaan untuk meningkatkan pendapatan dividen mereka.

Hubungan negatif antara institutional ownership dan utang sesuai dengan pendapat yang disampaikan Tong and Ning (2004) menyatakan struktur modal yang ditunjukkan dalam rasio leverage yang tinggi akan memberikan sinyal negatif. Sinyal negatif yang dimaksud karena investor menganggap hal tersebut sebagai gambaran bahwa kondisi keuangan perusahaan di masa yang akan datang yang lebih rentan pada kondisi kesulitan keuangan. Sehingga investor lebih tertarik pada leverage yang rendah.

\section{PENUTUP}

Berdasarkan analisis secara statistik dan pembahasan pada bab sebelumnya, maka simpulan untuk penelitian antara lain adalah board size berpengaruh negatif signifikan terhadap debt ratio perusahaan manufaktur di Indonesia, karena keberadaan dewan komisaris menyebabkan tekanan kepada para manajer untuk mengejar utang yang lebih rendah dalam meningkatkan kinerja perusahaan. Independent commisioner berpengaruh negatif signifikan terhadap debt ratio, karena dewan komisaris independen lebih aktif dalam memantau manajer yang akhimya menyebabkan manajer mengejar utang yang lebih rendah dalam pendanaannya. Managerial ownership tidak memiliki pengaruh terhadap keputusan pendanaan perusahaan manufaktur di Indonesia, karena manajemen sebagai pemegang saham minoritas tidak mempunyai cukup kendali dalam menentukan kebijakan utang karena kebijakan utang lebih banyak dikendalikan oleh pemilik mayoritas. Institutional ownership berpengaruh negatif terhadap keputusan pendanaan perusahaan karena investor institusional melakukan pengawasan yang lebih mendalam terhadap manajemen supaya menggunakan utang yang lebih rendah dalam pendanaan perusahaan untuk meningkatkan pendapatan dividen mereka.

Saran yang diajukan dari hasil penelitian ini adalah bagi investor agar dapat mempertimbangkan pemilihan portofolio saham sebelum menanamkan modalnya pada perusahaan dengan melihat kinerja perusahaan dan berdasarkan struktur utang dan penerapan good corporate governance yang dimiliki perusahaan. Bagi perusahaan, sebagai masukan yang dapat dijadikan tolak ukur pemikiran dalam menyusun suatu struktur modal yang optimum, dalam pembentukan struktur modal yang maksimum perusahaan perlu menerapkan corporate governance yang maksimal, maka dari itu perusahaan perlu memperhatikan boad size, board composition, dan profitabilitas perusahaan. Bagi penelitian selanjutnya, sebaiknya menggunakan variabel bebas yang lain seperti CEO tenure, board skill, atau peluang pertumbuhan, serta dilakukan pada perusahaan manufaktur pada tahun yang lebih baru. 


\section{DAFTAR PUSTAKA}

Abor, J. (2007). Corporate governance and Financing Decisions of Ghanaian Listed Firms, Corporate Governance: International Journal of Business in Society, 7: 83-92.

_ _ (2008). Determinants of The Capital Structure of Ghanaian Firms. AERC Research, 176.

Abor, J., and Biekpe, N. (2005). What determines the capital structure of listed firms in Ghana?, African Finance Journal, 7 (1): 37-48.

Anderson, R.C., Mansi.S.A., \& Reeb, D.M. (2005). Controlling managerial opportunism. Retrieved from: $\quad$ www.fma.org/Chicago/Papers/Controlling Managerial Opportunism.pdf.

Asbaugh., Hollis., Collins., Daniel W., Lafond., Ryan. (2004). Corporate governance and the cost of equity capital. Working paper, University of Wisconsin.

Al-Najjar, B., Peter Taylor. (2008). The relationship between capital structure and ownership structure: New evidence from Jordanian panel data, Managerial Finance, 34 (12): 919933.

Barnhart, S.W., \& Rosenstein, S. (1998). Board Composition, Managerial Ownership, and Firm Performance: An Empirical Analysis, Financial Review: 1-16.

Becht, M., Bolton, P. and Rosell, A. (2002). Corporate Governance and Control, w9371, National Bureau of Economic Research, Cambridge, MA

Berger, P.G., Ofek, E., \& Yermack, D.L. (1997). Managerial Entrenchment and Capital Structur Decisions.

Berglof, E., and von Thadden, E. (1999). The changing corporate governance paradigm: implications for transition and developing countries, paper presented at the Annual World Bank Conference on Development Economics, Washington, DC, 28-30 April.

Brailsford, T.J., Oliver, B.R., Pua, S.L.H. (1999). Theory and evidence on the relationship between ownership structure and capital structure. Retrieved from: http://papers.ssrn.com/sol3/papers.cfm? abstract_id=181888.

Brigham., Eugene F., and Joel F. Houston. (2001). Fundamentals of Financial Management, Ninth Edition. United States of America: Horcourt College

Caglayan, E. (2011). An Empirical Investigation on the Determinants of Capital Structures of Turkish Firms, Middle Eastern Finance and Economics: 35-42.

Chapra, M.U. (2008). Corporate Governance Lembaga Keungan Syariah. Bumi Aksara.

Claessens, S., Djankov, S., Fan, J.P.H. and Lang, L.H.P. (2002). Disentangling the incentive and entrenchment effects oflarge shareholders, The Journal of Finance, 57 (6): 2741-71. 
Cornett M.M., Marcuss, S.J., \& Tehranian, H. (2006). Earnings management, corporate governance, and true financial performance. Retrieved from: http://papers.ssrn.com/sol3/papers.cfm?abstract_id=886142.

Fidyati., Nisa. (2004). Pengaruh mekanisme corporate governance terhadap earnings management pada perusahaan seasoned equity offering (SEO), Jurnal Ekonomi, Manajemen dan Akuntansi, 2 (1): 1-23.

Friend, I., and Lang, L.H.P. (1988). An empirical test of the impact of managerial self-interest on corporate capital structure, Journal of Finance, 43 (2): 271-81.

Glen, J., and Pinto, B. (1994). Debt or equity? How firms in developing countries choose, Discussion Paper 22, International Financial Corporation, Washington, DC.

Ghozali, I. (2001). Aplikasi Analisis Multivariate dengan Program SPSS. Semarang: Badan Penerbit Undip.

Gompers, P.A., Ishii, J.L., and Metrick, A. (2003). Corporate governance and equity prices, Quarterly Journal of Economics, 118 (1): 107-55.

Hapsari, L. I. (2010). Analisis Faktor-Faktor yang Mempengaruhi Struktur Modal Perusahaan Manufaktur yang Terdaftar di Bursa Efek Indonesia Periode 2006-2008 (Studi Kasus pada Sektor Automotive and Allied Product). Skripsi tidak diterbitkan. Semarang: Universitas Diponegoro.

Hidayati, L. (2001). Analisis Faktor-Faktor yang Mempengaruhi Struktur Keuangan Perusahaan Manufaktur yang Go Public di Indonesia. Thesis.

Husnan, S. (2001). Dasar-Dasar Teori Portofolio dan Analisis Sekuritas, Edisi Ketiga. Yogyakarta: AMP YKPN.

Home, V., James C., dan John M. Wachowicz, Jr. (1998). Prinsip-prinsip Manajemen Keuangan, Alih Bahasa : Heru Sutojo, Buku Dua, Edisi Kesembilan. Jakarta: Salemba Empat.

Home, V., James C. (2002). Financial Management and Policy, 12th ed., Prentice Hall International Inc.

Juniarti, \& Sentosa, A. A. (2009). Pengaruh Good Corporate Governance, Voluntary Disclosure terhadap Biaya Hutang (Costs of Debt), Jurnal Akuntansi dan Keuangan, IH: 88-100.

Jensen, M.C. (1986). Agency costs of free cash flow, corporate finance and takeovers, American Economic Review, 76 (2): 323-9.

Kieso., Donal Edan Jerry J., Weygandt. (2001). Akuntansi Intermedite, Edisi kesepuluh. Jakarta: Erlangga. 
Lipton, M., and Lorsch, J.W. (1992). A modest proposal for improved corporate governance?, Business Lawyer, 48: 59-77.

Midiastuty., Pratana P., dan Mas'ud Machfoedz. (2003). Analisis Hubungan Mekanisme Corporate Governance dan Indikasi Manajemen Laba. Artikel yang Dipresentasikan pada Simposium Nasional Akuntansi 6 Surabaya tanggal 16-17 Oktober 2003.

Moh'd, Mahmoud A., Larry G. Perry., and James N. Rimbey. (1998). The Impact of Ownership Structure on Corporate Debt Policy: a Time-Series Cross • Sectional Analysis, The Financial Review, 33 (3): 85.

Pangaribuan, F.I. (2007). Pengaruh Corporate Governance terhadap Struktur Modal dan Kinerja Perusahaan: Studi Empiris pada Family Business Group yang Terdaftar di Bursa Efek Jakarta, Jurnal Riset Manajemen dan Bisnis, 2: 23-55.

Pfeffer, J. (1973). Size, composition and function of corporate boards of directors: the organisation-environment linkage, Administrative Science Quarterly, 18: 349-64.

Pfeffer, J., and Salancick, G.R. (1978). The External Control of Organisations: A Resourcedependence Perspective. New York, NY: Harper \& Row.

Prasetyantoko, A. (2008). Corporate Governance. Jakarta: Gramedia Pustaka Utama.

Rajeswararao, C., Damanpour Fariborz. (1991). Institutional Ownership, Capital Structure and Firm Performance, Strategic Management Journal, 12: 479-491.

Ross, S. A., Westerfield, R. W., \& Jordan, B. D. (2009). Pengantar Keuangan Perusahaan, 1 ed. 8. Jakarta: Salemba Empat.

Ross, S. A., Westerfield, R. W., \& Jordan, B. D. (2009). Pengantar Keuangan Perusahaan, 2 ed.8. Jakarta: Salemba Empat.

Riyanto, B. (2001). Dasar-Dasar Pembelanjaan Perusahaan, Edisi Keempat. BPFE: Yogyakarta.

Shleifer, A., \& Vishny, R.W. (1997). A Survey of corporate governance, Journal of Finance, 52 (2): 737-783.

Sugiyono. (2007). Metode Penelitian Kuantitatif, Kualitatif, dan R\&D. Bandung: Alfabeta.

Sukariana, I.W., and Darma, G.S. (2015). Peran Audit Dalam Pengendalian Internal Serta Pengungkapan Kerugian Material Untuk Good Corporate Governance, Jurnal Manajemen \& Bisnis, 12 (2): 181-194.

Tjager, I. N. (2003). Corporate governance: tantangan dan kesempatan bagi komunitas bisnis Indonesia. Jakarta: Prenhallindo. 
Vakilifard, H. R., Gerayli, M. S., Yanesari, A. M., \& Ma'atoofi, A. R. (2011). Effect of Corporate Governance on Capital Structure: Case of the Iranian Listed Firms, European Journal of Economics, Finance and Administrative Sciences: 165-172.

Widiatmika, P.H., and Darma, G.S. (2018). Good Corporate Governance, Job Motivation, Organization Culture Which Impact Company Financial Performance, Jurnal Manajemen \& Bisnis, 15 (3): 82-99.

Warsono, S., Amalia, F., \& Rahajeng, D.K. (2010). Corporate Governance Concept and Model. CGCG FE Ekonomi UGM.

Wen, Y., Rwegasira, K. and Bilderbeek, J. (2002). Corporate governance and capital structure decisions of Chinese listed firms, Corporate Governance: An International Review, Vol. 10 (2): 75-83.

Weston, J. Fred., dan Eugene F. Brigham. (2001). Dasar-Dasar Manajemen Keuangan. Erlangga: Jakarta.

Weston, J. Fred., dan Thomas E. Copeland. (1991). Manajemen Keuangan, Alih Bahasa: Yohanes Lamarto dan Mariana Adinata, Edisi Kedelapan, Jilid 2. Jakarta: Erlangga. www.iicg.org www. idx.co.id www.yahoofinance.com 